Jerzy Bartkowski

\title{
Iluzje fiskalne
}

\section{Uwagi wstępne}

Iluzje fiskalne są technicznym terminem z zakresu teorii finansów publicznych. Ogólnie iluzje fiskalne definiuje się jako społeczną tendencję do niedoszacowywania kosztów wydatków publicznych i przeszacowywania korzyści z programów publicznych dla jednostek ${ }^{1}$. W oryginalnym sensie tego pojęcia, użytego przez jego autora Amilcare Puvianiego, było ono definiowane jako proces polegający na ukrywaniu przez rządy prawdziwych „kosztów podatkowych" (taxcosts) ponoszonych wydatków publicznych. Iluzje fiskalne są konsekwencją stosowania podatków pośrednich, bardziej „niewidocznych” dla podatnika, jak też wykorzystywania zjawisk inflacyjnych do obniżenia realnej wartości ulg i zwolnień podatkowych, zamrażania progów podatkowych itp. Inna forma takich praktyk to ukrywanie podatków pod inną nazwą jako np. składki emerytalnej. Sprzyja temu zjawisko przerzucania podatku przez płatnika na konsumenta, prowadząc do tzw. ceno-podatków, ukrytych w płaconych cenach. Wszystko to powoduje, że podatnicy-wyborcy nie są świadomi zarówno rzeczywistych kosztów usług publicznych, jak i wielkości własnych danin.

$\mathrm{W}$ tym tekście iluzje fiskalne będą traktowane nieco szerzej jako różnego rodzaju potoczne poglądy czy stereotypy na temat finansów publicznych. Iluzje fiskalne obejmują społeczne przekonania o właściwym kształcie systemu podatkowego, pożądanym kształcie wydatków państwa i relacji podatki-wydatki. Są to zarówno stereotypy społeczeństwa, jak i polityków. Tak rozumiane iluzje fiskalne dotyczą korzyści i strat związanych z decyzjami w sferze wydatków

\footnotetext{
* Doktor habilitowany, profesor UW, Uniwersytet Warszawski, Wydział Filozofii i Socjologii Zakład Socjologii Polityki.

1 R. Musgrave, P. Musgrave, Public Finance in Theory and Practice, New York 1989, s. $100-101$.
} 
publicznych i poboru podatków. Szereg iluzji powstaje w wyniku odrębnego postrzegania sfery wpływów i wydatków budżetowych. Groźną iluzją jest także przekonanie, że wydatki publiczne dla społeczeństwa, czy inne świadczenia na jego rzecz w różnej formie, odbywają się na koszt państwa, a nie społeczeństwa. Stąd płynie prosty wniosek, że realizacja hojnych obietnic wyborczych polityków wzbogaci społeczeństwo bez żadnych strat z jego strony, a najlepszym dla niego kandydatem jest ten, który obiecuje mu najwięcej.

Iluzje fiskalne mogą być mobilizowane i wykorzystywane w walce wyborczej, a w skrajnej postaci przybierają formę populizmu fiskalnego. Nazywanie ich nowoczesnymi mitami byłoby niewłaściwie, gdyż to zjawisko jednak jakościowo odmienne. Jest jednak sporo w nich podobieństw z mitami. Przemawia za tym przede wszystkim ich nie tylko nieracjonalny, ale ponadracjonalny charakter. Nie podlegają weryfikacji, ale na odwrót. To one są tym pierwotnym czynnikiem, który nadaje wartość różnym innym zjawiskom, jak programy wyborcze czy działania polityczne.

Pokrewieństwo iluzji fiskalnych z mitami ukazuje także ich niezależność od weryfikacji logicznej. Występują one w jednej z najbardziej zracjonalizowanych i zmatematyzowanych dyscyplin nauk społecznych. Jest to dziedzina cała zbudowana wokół pojęć rachunku strat i korzyści, która dysponuje szeregiem narzędzi sprawdzania ich efektów w konkretnych sytuacjach. W praktyce dyskurs publiczny rzadko się jednak do nich odwołuje, a jeśli się taka weryfikacja pojawia, często przez opinię publiczną nie jest przyjmowana jako argument.

Propozycja spojrzenia na iluzje fiskalne poprzez teorię mitu politycznego pokazuje ich pozaekonomiczne funkcje i związki z wartościami. Są one tak samo jak mity powiązane ze światem wartości, szczególnie $z$ historycznym pojęciem sprawiedliwości społecznej - sprawiedliwości rozdzielającej i wyrównującej, używając klasycznych pojęć etycznych. Wyrażają one potrzebę sprawiedliwości społecznej, często w prostej i bezpośredniej formie, jak kara za bogactwo w postaci podatku.

Dodatkowo są one elementem szerszego zjawiska - sposobu podejmowania decyzji przez społeczeństwo w demokracji. Ukazują one dobitnie mechanizm formowania się opinii publicznej. Zachodzi to nie tylko w warunkach niepełnych informacji, i przy ich znaczącej redukcji, ale przy deformacji tych elementów decydowania, które pełnią rolę przesłanek. Istnienie iluzji i ich oddziaływanie na opinię publiczną jest argumentem za rolą edukacji obywatelskiej, nawet $\mathrm{w}$ dziedzinie wydawałoby się tak odległej od zainteresowań przeciętnego obywatela jak finanse publiczne. 


\section{2. lluzje fiskalne - różne ujęcia teoretyczne}

Iluzje fiskalne, rozumiane przez klasyków teorii finansów publicznych - Jamesa Buchanana, Richarda Musgrave’a czy Wallace’a Oatesa - jako błędne postrzeganie wielkości płaconych podatków i uzyskiwanych korzyści od państwa, mają szereg zjawisk pokrewnych, które łączy pole - finanse publiczne. Wydaje się, że powinno się je ująć razem w szerszym rozumieniu zjawiska iluzji fiskalnych. Ograniczanie się do pierwotnej kategorii niepotrzebnie zawęziłoby zakres analizowanego zjawiska bez istotnych korzyści poznawczych. Tak więc, $w$ tym tekście iluzje fiskalne dyskutowane będą w szerszym sensie jako powszechnie przyjęte przekonania dotyczące zjawisk ze sfery finansów publicznych.

Iluzje fiskalne dotyczą takich kwestii, jak: kto i ile powinien płacić podatków, co powinno być przedmiotem opodatkowania, a także jaka powinna być wysokość wydatków i na co powinny być przeznaczane. Nie stanowią one systemu powiązanych ze sobą wyobrażeń. Charakteryzują się brakiem wewnętrznej spójności, wynikającym $\mathrm{z}$ odrębnego postrzegania każdego z fragmentów systemu i oddzielnego formułowania wobec nich swych oczekiwań. Iluzje fiskalne nie biorą się tylko z „powietrza” czy z ludowych pojęć o ekonomii i sprawiedliwości. Mają one swe uwarunkowania psychologiczne, instytucjonalne i społeczne. Iluzje fiskalne bywają także zakorzenione w panujących ideologiach, modnych teoriach ekonomicznych i w stereotypach politycznych. $\mathrm{Na}$ ogół nie znajdują potwierdzenia w faktach, a w skrajnych przypadkach mogą prowadzić do konsekwencji odwrotnych od skutków przez nie obiecywanych.

Istnieje kilka ujęć tego zagadnienia, które jednocześnie ukazują różne wymiary tego zjawiska. Pierwsze $\mathrm{z}$ nich to ujęcie ich jako problemu podejmowania decyzji w warunkach niepełnych informacji (Wallace Oates) i zarazem część szerszego problemu decydowania przez wyborcę/obywatela w demokracji. Jest to ujmowanie ich w kategoriach konsekwencji niewiedzy i pewnego rodzaju błędu poznawczego popełnianego w skali masowej.

Drugie ujęcie to iluzje fiskalne jako ideologia w sferze finansów publicznych (Amilcare Puviani). Nawiązuje ono do Marksowskiego pojęcia ideologii. Iluzje maskują przed płatnikiem jego wyzysk, a zwiększają poczucie korzyści. To ważny aspekt zjawisk fiskalnych, ale niewyczerpujący. Choć jest to nieco przerysowane ujęcie funkcji iluzji fiskalnych, jednak nie można tego punktu widzenia pominąć. James Buchanan proponuje widzieć w tym instytucjonalnie produkowaną wiedzę. Inaczej mówiąc, dostrzega w nich konsekwencje pewnej sytuacji - określony kształt instytucji podatkowych powoduje spaczone o nich wyobrażenia.

Trzecie ujęcie iluzji fiskalnych to ich percepcja w kategoriach wymiany rządzący-rządzeni. Można tu zaliczyć niektóre interpretacje residuum 
podatkowego Wicksella. To ujęcie przyjmuje, że rząd jest producentem określonych usług, które społeczeństwo „nabywa” za cenę podatków. Jednocześnie sugeruje ono strukturalnie nieekwiwalentną postać tej wymiany.

Jako czwarte ujęcie iluzji fiskalnych można wskazać na moralizatorstwo podatkowe - prymarne powiązanie podatków ze sferą szeroko rozumianej sprawiedliwości społecznej i jako pole jej realizacji.

Każde z proponowanych ujęć ukazuje ważny aspekt zjawiska iluzji fiskalnych, zarazem nie można tychże aspektów uznać za jedyne wytłumaczenie tego fenomenu. Należy w nich postrzegać jego komplementarne ujęcia. Stąd praca ta omawia je łącznie.

Iluzje fiskalne to niewątpliwie istotne, ważne i realne zjawiska. Mają one szereg przyczyn i wymiarów. Razem wpływają na społeczną percepcję tego zjawiska i mogą prowadzić do podejmowania decyzji o negatywnych skutkach społecznych.

\subsection{Iluzje podatkowe jako zjawisko poznawcze (Wallace Oates)}

Wallace Oates sformułował teorię iluzji fiskalnych jako zjawisk poznawczych - zdeformowanych sposobów postrzegania tej sfery życia społecznego. Według niego występuje pięć form i źródeł iluzji fiskalnych:

1. Złożoność struktury podatkowej: podatki pośrednie, podatki $\mathrm{w}$ formie potrąceń z pensji, składek, opłat i biletów, ubezpieczenia, które powodują rozmycie postrzegania wielkości realnego wkładu podatkowego.

2. Efekt „właściciela domu” i „lokatora”. Ten typ iluzji fiskalnej jest dobrze widoczny w lokalnej polityce podatkowej. Występują w niej właściciele domów, płacący podatek od nieruchomości i mieszkańcy - lokatorzy domów, beneficjenci tych polityk. Tych drugich jest większość. Wynajmujący, którzy bezpośrednio nie płacą lokalnych podatków od nieruchomości, skłonni są, by głosować za rozszerzeniem lokalnych usług. Teoria iluzji fiskalnych sugeruje, że mogą oni popierać taką politykę, ponieważ jej koszt jest zamaskowany przed nimi przez jej pośredni charakter. Lokator oczekuje wielu różnych świadczeń od gminy, gdyż spodziewa się po tym korzyści dla siebie, które uzupełnią jego dobrobyt. Przy takim wyborze polityk podatkowych, wydaje mu się, że nie ma to wpływu na jego dochód realny. W rzeczywistości jednak tak nie jest. Wpływa to na jego dochód, gdyż podnosi cenę za mieszkanie za pośrednictwem czynszu. Wzrost podatków zostanie sfinansowany ze wzrostu podatków od nieruchomości, a to spowoduje wzrost czynszu, jaki lokator będzie musiał zapłacić. Efekt lokatora i domu można uogólnić i przenieść na inne sfery władzy. Przypomina on relacje wyborca-państwo. Efekt ten jest wynikiem 
odrębnego tworzenia oczekiwań polityk publicznych, wtedy gdy się formują w oderwaniu od myślenia o środkach na nie przeznaczanych.

3. Iluzja finansowania przez dług - jest to wiara, że lepsze jest finansowanie przez kredyt publiczny niż przez wyższy wysiłek daninowy. Prowadzi to do popierania wzrostu długu publicznego. Kredyt i pożyczki są droższe od danin bezpośrednich.

4. Większe znaczenie przypisuje się stopie opodatkowania niż sumarycznej kwocie podatku. W rezultacie większy opór budzi zmiana stopy opodatkowania niż płacenie wyższej kwoty podatku przy zachowaniu dotychczasowej stopy opodatkowania.

5. Efekt „lepu” (the flypaper effect) przejawia się w tym, że kiedy wyższy poziom władzy dostarcza dotacje niższym szczeblom, to te nie redukują lokalnych danin, na czym by skorzystali lokalni podatnicy, ale rozszerzają zakres lokalnych usług i zwiększają wydatki. Teoria fiskalnych iluzji wyjaśnia to tym, że podatnicy lokalni nie są w pełni świadomi, że dotacje są dochodem władz lokalnych.

Także w praktycznych prawach skarbowości są zawarte pewne obserwacje o charakterze psychologicznym. Już jedna z zasad podatkowych Adama Smitha brzmiała, aby podatki pobierać $w$ momentach korzystnych dla podatnika - wtedy, gdy dysponuje on większą gotówką, np. u rolników po żniwach, a nie na przednówku². Wtedy też jego subiektywne odczucie straty jest mniejsze. Innym przykładem jest prawo, że postrzeganie uciążliwości podatku jest funkcją jego „wieku”. Zauważono to już dawno. „Tout vieil impôtest bon et tout nouvel impótest mauvaiss” („Dobry podatek, to stary podatek”) - powiada Canard w swych Principes d'economie politique $(1801)^{3}$. Stąd płynie postulat stałości systemu podatkowego. Jest to przejaw działania takiej prawidłowości psychologicznej, jak nawyk w sferze podatkowej.

To nie wyczerpuje roli czynników psychologicznych w opodatkowaniu. Niektóre z nich omawia Andrzej Gomułowicz w pracy o zasadzie sprawiedliwości podatkowej ${ }^{4}$. Tacy autorzy jak Gustav Schmölders uznają nawet psychologię fiskalną za odrębne pole badawcze. Obejmuje ono postawy wobec podatków: poczucie obciążenia podatkowego i opór podatkowy, moralność podatkową, mentalność podatkową (poczucie sprawiedliwości podatkowej) czy szerzej - państwo w świadomości społecznej j $^{5}$ Socjologia fiskalna Fritza Manna i Juergena Backhausa z kolei szuka społecznych elementów w finansach publicznych, jak

\footnotetext{
F. Grądalski, Wstęp do teorii opodatkowania, Warszawa 2004, s. 136-137.

Cyt. za: F. Zweig, Przerzucanie podatków, Kraków 1923, s. 74.

A. Gomułowicz, Zasada sprawiedliwości podatkowej, Warszawa 2001, s. 93-96.

G. Schmölders, Finanz- und Steuerpsychologie, [w:] Handwörterbuch der Wirtschaftswissenschaft, t. 3, Stuttgart-New York-Tübingen-Göttingen-Zürich 1972-1983, s. 123-135.
} 
i fiskalnych elementów w życiu społecznym ${ }^{6}$. W obu tych ujęciach pojawiają się czynniki pozafinansowe w zjawiskach fiskalnych. Jest to irracjonalizm lub systemowe skrzywienie o korzeniach psychologicznych lub społecznych.

Warto zaznaczyć, że lokowanie iluzji w różnych sferach, zarazem jest dyskusją nie tylko nad ich naturą, ale i poszukiwaniem możliwych środków zaradczych. W poznawczym ujęciu jest to kwestia trudności percepcji złożoności, danej odmiennie czasowo, przestrzennie i społecznie. Powoduje to trudność zbudowania związku przyczynowo-skutkowego między nimi, tendencję do konserwatyzmu poznawczego i do błędów atrybucji. Za jego psychologicznym umiejscowieniem przemawia to, że w tym ujęciu wydaje się ono być bardziej konsekwencją psychologicznego aparatu człowieka niż działania struktur społecznych, administracyjnych czy politycznych. Nie jest ona także zależna od umiejscowienia tego zjawiska w strukturze panowania. Ujęcie poznawcze stwarza więc nadzieję, że także drogą poznawczą, taką jak perswazja, można efekty tych iluzji osłabić, a nawet zniwelować.

\subsection{Iluzje fiskalne jako socjotechnika władzy (Amilcare Puviani)}

W ujęciu Amilcare Puvianiego instrumenty fiskalne stanowią element porządku instytucjonalno-politycznego, wykorzystywanego przez grupę rządzącą w celu zminimalizowania oporu podatników wobec nadmiernych obciążeń podatkowych. Klasa panująca kreuje iluzje fiskalne, polegające na sugerowaniu podatnikom, że poziom podatków jest niższy niż w rzeczywistości, natomiast realna wartość dóbr i usług, których są beneficjentami jest wyższa ${ }^{7}$. To często spotykane ujęcie iluzji. Powstanie tej teorii wiąże się z elitystyczną epoką we włoskiej socjologii, ekonomii i filozofii polityki ${ }^{8}$. Należy przypomnieć, że Puviani działał równolegle do Parety, który stworzył teorię ludzkich zachowań nielogicznych?

6 F.K. Mann, Finanzsoziologie, [w:] Handwörterbuch der Sozialwissenchaften, t. 2, Stuttgart-Tübingen-Göttingen 1961, s. 642-648; J. Backhaus, Fiscal Sociology: What For?, https://www.uni-erfurt.de/fileadmin/user-docs/Finanzwissenschaft/bibliothek/valedictory_lecture.pdf [dostęp: 1.05.2018].

7 B. Guziejewska, Iluzje fiskalne w zdecentralizowanych systemach finansów publicznych, [w:] Finanse lokalne. Wybrane zagadnienia, L. Patrzałek (red.), Poznań 2009, s. 59-68.

8 M. Ferrari-Occionero, Myśl socjologiczna Roberta Michelsa, „Studia Socjologiczne” 1985, nr 2, s. 161-172.

9 V. Pareto, Uczucia i działania: fragmenty socjologiczne, Warszawa 1994. James Buchanan przytacza fragment listu Parety do Sensiniego: „podatnik, którego uważa się za dążącego do maksymalizowania pożądalności [wł. ofelimita] stanowi tylko część, częstokroć bardzo niewielką zjawiska. Podatnik nie zna wielu spośród skutków, jakie dają podatki, czy też, ogólniej i słuszniej skutków, jakie dają liczne transakcje finansowe; stąd też jego działania 
Tak iluzje fiskalne przedstawia też James Buchanan, pisząc, że grupa rządząca usiłuje, w miarę możliwości, kreować iluzje fiskalne, które mają wytworzyć w podatnikach złudzenie, iż ciężar podatków jest mniejszy, niż jest w rzeczywistości. Jednocześnie tworzy się inne złudzenia, które sprawiają, że beneficjenci sądzą, iż wartość dóbr i usług publicznych im dostępnych jest większa niż realna. Różnorodne instytucje podatkowe i wydatkowe są zorganizowane w taki sposób, żeby takie iluzje utwierdzać ${ }^{10}$.

Iluzja fiskalna jawi się w tym ujęciu jako ideologia - władze publiczne zamazują lub ukrywają związki pomiędzy wysokością indywidualnych obciążeń podatkowych i quasi-podatkowych a pożytkami odnoszonymi przez podatnika korzystającego z szeroko rozumianych usług publicznych. W tym celu w systemie podatkowym wykorzystuje się podatki pośrednie, ukryte w cenach dóbr i usług, których istnienia podatnik może nie być świadomy lub po prostu w danej sytuacji ich nie łączy ze świadczeniem na rzecz państwa. Konstrukcja podatków od towarów i usług powoduje błędne wrażenie lub wprost niezrozumienie, kto ponosi ciężar podatku.

Iluzje fiskalne minimalizują opór podatnika przeciw opodatkowaniu. Oparcie systemu podatkowego na wielu tytułach podatkowych utrudnia mu zaobserwowanie jego sumarycznej wielkości. Traci on kontrolę nad wielkością swojego wkładu w państwo. Z kolei inne iluzje powodują ocenianie in plus korzyści, jakie otrzymuje lub może otrzymać.

Przyczyną ich akceptacji jest izolowane postrzeganie poszczególnych aspektów polityki finansowej państwa. Ocena działań, zjawisk czy zachowań w sferze finansów publicznych dokonuje się w zniekształconej perspektywie. To zniekształcenie dokonuje się właśnie tam, gdzie dobre ujęcie bilansu czy ujmowanie zjawisk przyczynowo-skutkowych jest szczególnie ważne.

Rozbudowaną listę iluzji fiskalnych zestawiła Beata Guziejewska, w podziale na sferę opodatkowania, wydatków i bilansu podatki-wydatki. Ta lista pozwala się zorientować w zakresie zjawiska. Pokazuje ilość różnych form, pod jakimi mogą występować podatki i uzmysławia, jak trudno uzyskać przeciętnemu obywatelowi w nich orientację, w szczególności jak trudno mu się zorientować w ich kluczowych aspektach, takich np. jak ich bilans ${ }^{11}$.

nie mają charakteru działań podyktowanych logiką, jak to jest w sytuacji ekonomii politycznej, której teoria okazuje się łatwiejsza. Mają one jednak charakter działań nielogicznych, których teoria jest znacznie trudniejsza" (J. Buchanan, Finanse publiczne w warunkach demokracji. Systemy fiskalne a decyzje indywidualne, Warszawa 1997, s. 159-160).

10 Ibidem, s. 163.

11 Ze względu na szczupłość miejsca została pominięta problematyka zasad budżetowych. Dotyczą one zasad konstruowania i prezentacji budżetu. Mają one na celu umożliwienie demokratycznej kontroli budżetu przez wgląd w jego kluczowe parametry jak jego 
Beata Guziejewska podzieliła iluzje na trzy grupy - występujące w sferze dochodów państwa, na polu jego wydatków i w obszarze bilansu budżetu państwa. W obszarze dochodów publicznych iluzje fiskalne związane są przede wszystkim z następującymi okolicznościami:

1) władze publiczne zamazują lub ukrywają związki pomiędzy wysokością indywidualnych obciążeń podatkowych i quasi-podatkowych a pożytkami odnoszonymi przez podatnika korzystającego z szeroko rozumianych usług publicznych;

2) w systemie podatkowym wykorzystuje się podatki pośrednie, ukryte w cenach dóbr i usług, których istnienia podatnik może nie być świadomy lub po prostu w danej sytuacji nie łączy zwiększenia wydatków publicznych ze zwiększeniem podatków o takim charakterze; konstrukcja podatków od towarów i usług powoduje błędne wrażenie lub niezrozumienie, kto tak naprawdę, z ekonomicznego punktu widzenia, ponosi ciężar podatku;

3) oparcie systemu podatkowego na wielu tytułach podatkowych i na różnych szczeblach terytorialnego podziału kraju może sprzyjać wrażeniu, iż obciążenie podatkami jest mniejsze niż w sytuacji nałożenia obciążenia na jeden przedmiot opodatkowania;

4) podobnie działa efekt podziału całkowitej płatności na wiele mniejszych płatności, płaconych w różnych okresach;

5) w praktyce zauważa się tendencję do nadużyć terminologicznych i nazywania podatków opłatami, składkami publiczno-prawnymi. Wysokość takich obciążeń quasi-podatkowych może być nie mniejsza niż obciążenia nazwane przez ustawodawcę podatkowymi. Podatki występują pod wieloma innymi nazwami, np.: jako przymusowe ubezpieczenie autocasco, ubezpieczenie od bezrobocia, jako składka na cele emerytalne lub na ubezpieczenia zdrowotne;

6) politycy i administracja publiczna wykorzystują emocje i konflikty społeczne dla celów fiskalnych, np. negatywne emocje wobec pewnej grupy dla zwiększenia podatku przez nią płaconego lub pozbawienia jej tytułu prawnego pozwalającego na jego zmniejszenie;

7) jeśli jakaś konkretna postawa jest rozpowszechniona w społeczeństwie, można nałożyć na nią ukryty podatek, zbijając z niej kapitał. Płatnicy zyskują przeświadczenie, że ogólny ciężar daninowy jest mniejszy niż

źródła, kierunki wydatków i relacja wydatków i dochodów. Zasady podatkowe omawiają Andrzej Gomułowicz (A. Gomułowicz, Zasady podatkowe wczoraj i dziś, Warszawa 2001) i Maria Kosek-Wojnar (M. Kosek-Wojnar, Zasady podatkowe w teorii i praktyce, Warszawa 2012). 
w rzeczywistości. Przykładem tego mogą być występujące w Polsce po wojnie wpłaty na SFOS (Społeczny Fundusz Odbudowy Stolicy). Powstał on w 1948 roku. W roku 1958 został zamieniony na Społeczny Fundusz Odbudowy Kraju i Stolicy (SFOKiS). W 1966 roku SFOKiS przekształcono w Społeczny Fundusz Budowy Szkół i Internatów. Ten ostatni był łączony ze współdziałaniem z władzami w akcji „Budowy 1000 szkół na Tysiąclecie”. W 1973 roku zmienił on nazwę na Narodowy Fundusz Ochrony Zdrowia. W tej postaci dotrwał do końca PRL. Obecnie stanowi organizację pożytku publicznego zbierającą fundusze na wyposażenie dla szpitali. Pewną odmianą tej formy opodatkowania było w PRL oszczędzanie na spółdzielczą książeczkę mieszkaniową. Był to podatek od dzieci, nałożony na rodziców, którzy tę składkę w zastępstwie swych nieletnich latorośli opłacali. Ze względu na małe szanse na szybką realizację tych oczekiwań, można go nazwać opodatkowaniem ludzkiej nadziei i miłości do dzieci;

8) rząd - po to, by zagwarantować sobie powszechną akceptację podatku - straszy państwo najgorszymi skutkami, jeśli tylko zdarzy się, że nałożenie podatku nie spotyka się z aprobatą. Trzeba zaznaczyć, że argumenty o ograniczonych możliwościach finansowych często bywają nadużywane, niekiedy nawet na wysokim szczeblu decyzji, jak w procedurze parlamentarnej.

W obszarze wydatków publicznych iluzje mogą być wywołane przez:

1) nieeksponowanie faktu, że sektor budżetowy nie wypracowuje bezpośrednio żadnych dochodów, zgłaszając zapotrzebowanie na pieniądz, sięga zawsze do dochodów wypracowanych przez inne podmioty;

2) stwarzanie wrażenia, że wydatki publiczne finansowane są z bliżej nieokreślonych źródeł lub że ich wzrost nie spowoduje wcześniej czy później podniesienia obciążeń podatkowych. Można do tego dodać wątek postrzegania państwa jako niewyczerpanego źródła zasobów, szczególnie, jeśli cel wydatkowania jest „słuszny”. To pierwsze przypomina nieco sposób patrzenia przez dziecko na matkę-karmicielkę, która ma na wszystko środki i zawsze je znajdzie. Na szczeblu lokalnym ta iluzja fiskalna to przekonanie części mieszkańców, że wydatki finansowane przez wyższy szczebel ich samych nic nie kosztują;

3) finansowanie wydatków może nastąpić na skutek drukowania tzw. pustego pieniądza lub wykorzystania inflacji powodującej wzrost cen, w których zawarty jest podatek;

4) wykorzystywanie przez państwo skomplikowanych technik rachunkowych, bardzo różnych klasyfikacji wydatków publicznych w celu ukrywania rzeczywistej wysokości lub charakteru programów budżetowych i polityki fiskalnej; 
5) rozmywanie rzeczywistych kosztów polityki władz publicznych, utrudnianie rzeczywistej kontroli nad wysokością i strukturą ogółu wydatków publicznych (zarówno budżetowych, jak i parabudżetowych, na szczeblu zarówno państwa, jak i samorządu terytorialnego);

6) niezrozumienie, jak ważne są cele, na jakie przeznacza się środki publiczne oraz czy wydatki mają charakter bieżący, czy inwestycyjny, prorozwojowy; ma to znaczenie tym bardziej, że wydatki te w naturalny sposób konkurują ze sobą i często górę biorą bieżące korzyści polityczne, a nie perspektywa długookresowa w zaspokajaniu potrzeb społecznych;

7) można „przejściowo” zwiększać wydatki. Takie „chwilowe” zwiększenie wydatków publicznych nabiera często charakteru trwałego, raz zwiększone wydatki bardzo trudno ograniczyć ze względu na określone grupy ich beneficjentów, które będą ich bronić.

Jeśli chodzi o saldo dochodów i wydatków, czyli deficyt budżetowy, to iluzje fiskalne mogą być związane z takimi okolicznościami, jak:

1) zaciąganie pożyczek publicznych, które zwiększa jedynie przejściowo możliwości wydatkowe budżetu publicznego. Ukrywa się fakt, iż spłata pożyczek w przyszłości możliwa będzie jedynie w drodze zwiększenia wysokości podatków;

2) zadłużanie się władz publicznych na cele bieżące może prowadzić do wzrostu wydatków publicznych poza zakres społecznie optymalny, wynikający z poziomu obciążeń podatkowych, jakie podatnicy chcą ponosić, aby sfinansować pożądany zakres i jakość usług publicznych;

3) dla polityków bardzo wygodne może być przyjęcie poglądów związanych $\mathrm{z}$ teorią interwencjonizmu państwowego i przekonywanie wyborców o neutralności długu publicznego dla gospodarki;

4) zadłużanie się władz publicznych może oznaczać jedynie odsuwanie $\mathrm{w}$ czasie nieprawidłowości $\mathrm{w}$ finansach publicznych i przerzucanie ich kosztów na przyszłe pokolenia;

5) zakup przez podatnika bezpiecznych, skarbowych papierów wartościowych może wytworzyć iluzję, że podatnik chroni swoje oszczędności i korzysta $z$ dochodów w postaci odsetek. Nie zdaje on sobie sprawy, że w całkiem nieodległej przyszłości władze publiczne mogą być zmuszone pokryć wydatki na spłatę swych długów i ich obsługę, podnosząc podatki ${ }^{12}$.

Warto wskazać na dwa istotne aspekty teorii iluzji fiskalnych jako ideologii. Po pierwsze, pojawia się w niej trochę nietypowe rozumienie jej roli. Tutaj pokazuje się jej możliwą dodatnią stronę - „pozytywnej iluzji”. Funkcja ideologii,

12 B. Guziejewska, op. cit., s. 62-64. Por. także listę iluzji fiskalnych u Jamesa Buchanana

(J. Buchanan, op. cit., s. 163-170). 
jaka się tu jawi, to uczynienie sytuacji „wyzysku” łatwiejszą do zniesienia lub choćby mniej zauważalną.

Po drugie, James Buchanan traktuje to zagadnienie szerzej i nie zawęża go do samej sfery cynizmu czy makiawelizmu rządzących. Stawia tezę, że mimo wyraźnego związku zjawiska z interesami klasy rządzącej, można także rozumieć ten efekt „bezpodmiotowo”. Byłoby to zjawisko, które formuje się żywiołowo $\mathrm{w}$ następstwie rozproszenia instytucjonalnego momentu realizacji zobowiązania podatkowego i jego zasadniczej separacji od wydatków państwa. Zdaniem Buchanana, należy więc rozważać działanie różnych instytucji fiskalnych pod kątem ich zdolności do generowania takich iluzji ${ }^{13}$. Iluzje fiskalne są dla niego nie tylko wynikiem „makiawelizmu” klasy rządzącej, ale można w nich widzieć produkt uboczny budowy systemu instytucjonalnego. Dla analizy społecznych mechanizmów funkcjonowania życia społeczeństwa ważne jest samo istnienie zjawiska, a nie jego społeczna geneza lub polityczna funkcja. $\mathrm{Z}$ jego efektami muszą się liczyć zarówno politycy demokratyczni, jak i niedemokratyczni.

\subsection{Podatek jako wymiana usług rządzący-rządzeni}

Podatek można także postrzegać przez matrycę wzajemnej wymiany usług rządzący-rządzeni. Jako podstawę teoretyczną dla takiej koncepcji percepcji podatku można przyjąć pojęcie residuum finansowego wprowadzone przez szwedzkiego ekonomistę Knuta Wicksella. W jego koncepcji oznacza ono saldo powstałe z porównania świadczeń na rzecz państwa poniesionych przez określoną jednostkę z korzyściami, jakie ona czerpie z usług świadczonych przez państwo. Ta zasada czasem nazywana jest zasadą ekwiwalentności. Pozostaje ona w ścisłym związku z szukaniem modelu „podatku sprawiedliwego”. Dążenie do ekwiwalentności podatków i świadczeń, nakładów i korzyści, można uznać za jego dobrą podstawę ${ }^{14}$.

Jednak taką percepcję relacji państwo-obywatel można też wykorzystywać populistycznie. Przykładem może być corocznie ogłaszany w Polsce przez Centrum im. Adama Smitha tzw. dzień „wolności” podatkowej. Jest to dzień w roku, w którym korzyści, jakie uzyskuje obywatel, zrównują się z podatkami - wypada to zwykle na początku lata. Oblicza się go od 1994 roku. W tym okresie wahał się on między 11 czerwca a 7 lipca. Wskazuje to na pewien bardzo ważny aspekt systemu podatkowego, jakim jest możność marnotrawstwa grosza publicznego przez państwo. Nie jest to czysto wydumane niebezpieczeństwo, ale bardzo realny problem.

13 Ibidem, s. 158.

14 F. Grądalski, op. cit., s. 54-58, 120-125. Omawia także tę teorię Andrzej Gomułowicz. Por. A. Gomułowicz, Zasada sprawiedliwości..., s. 64-66. 
Jednak wydaje się, że główna wada tego podejścia polega na tym, że operuje ono indywidualnym rachunkiem jednostka-społeczeństwo. $Z$ jednej strony, część korzyści z istnienia państwa jednostka uzyskuje jako uczestnik ładu zbiorowego w formach konsumpcji zbiorowej. Przy czym część tych korzyści jest odroczona w czasie, jak emerytury. $Z$ drugiej strony jednak, państwo jest także formą zbiorowych ubezpieczeń wzajemnych i zbiorowej solidarności w wymiarze tak aktualnym, jak i międzypokoleniowym.

$\mathrm{Z}$ takim rozumieniem kwestii podatków blisko jest związana tendencja opinii publicznej do przeceniana wysokości płaconych podatków i równoległa tendencja do postrzegania ich jako niewłaściwie wydatkowanych. Istnieje sporo na to dowodów w badaniach socjologicznych.

Częsta jest ocena wysokości podatku jako nadmiernego. W ankietach badających tę kwestię z użyciem skali: czy podatek jest za duży, w sam raz, za mały - prawie nigdy nie jest wybierana odpowiedź „za mały”. Można przytoczyć przykład z sondaży polskich i amerykańskich. W badaniach Instytutu Gallupa zadawane jest corocznie pytanie: „Czy myśląc o podatkach, uważa Pan/i/, że wielkość podatku dochodowego, jaki Pan/i płaci jest za duża, właściwa czy za niska?”. W okresie 1947-2008 odpowiedź „za niska” wybierało 1-2\% badanych. Raz tylko w całym tym okresie odpowiedź ta osiągnęła wielkość $3 \%{ }^{15}$. W Polsce takie badanie zrealizował CBOS w 1994 roku. Większość badanych (76\%) uznała podatki za wysokie, a tylko $1 \% \mathrm{za}$ - zbyt małe ${ }^{16}$.

Z tymi wynikami blisko korespondują efekty badania przeprowadzonego na zlecenie „Polityki”. Ich omówienie pobudziło autora badania, Mariusza Janickiego, do następujących refleksji:

Niestety, mimo edukacji szkolnej i życiowej, praktykowania już trzecią dekadę kapitali-
zmu i demokracji, mamy skłonność do widzenia wszystkiego oddzielnie. Więc jednym
tchem możemy popierać i postulat wyższych cen skupu żywności, i nie zgadzać się na
wyższe ceny jej sprzedaży; żądać i niższych podatków, i wyższych świadczeń społecz-
nych; odrzucać pomysł podniesienia składek zdrowotnych i domagać się finansowania
wszystkich dostępnych procedur medycznych dla każdego; popierać ponowną obniżkę
wieku emerytalnego i oczekiwać podwyżki "głodowych” emerytur, ale bez podwyż-
szania składek emerytalnych, bo kogo i na to stać itp. Każda z tych sprzecznych opcji
będzie miała w badaniach większośćl

15 K. Bowman, E. O’Neil, F. Sims, Public Opinion on Taxes: 1937 to Today, http://www. aei.org/publication/aei-public-opinion-study-public-opinion-on-taxes-1937-to-today/ [dostęp: 1.11.2015].

16 Komunikat BS/8/7/94 z 17.01.1994 r., CBOS, Warszawa 1994, s. 3.

17 Badanie przeprowadzono $\mathrm{w}$ dniach 27.02-4.03.2015 r. na reprezentatywnej próbie tysiącosobowej techniką wywiadów bezpośrednich CAPI (M. Janicki, Badania nad żądaniami, „Polityka” 2015, 8.03.). 
Konsekwencją tego ogólnego negatywnego nastawienia jest podatność na negatywne wartościowanie każdego opodatkowania jako takiego. Można to zauważyć w odniesieniu do takich jego form, jak dotacja wyrównująca i opłata uzdrowiskowa. Dotacja wyrównująca dochody - jest konsekwencją rozbieżności między obszarem wypracowywania i miejscem płacenia (obszarem, z jakiego pochodzi dochód firmy a lokalizacją centrali). Obowiązek pomocy słabszym samorządom jest wpisany w Europejską Kartę Samorządową. Jednak utarło się nazywać ten podatek ,janosikowym”. Generuje on zbiorowe poczucie krzywdy u jego płatników. To kolejny przykład wskazujący na performatywną rolę języka w finansach - tworzy on pewną rzeczywistość, a nie tylko ją opisuje ${ }^{18}$.

W konsekwencji powoduje to społeczne potępienie tego podatku, mimo że zrealizowanie postulatu jego likwidacji spowodowałoby efekt jeszcze wyższej koncentracji przychodów w rękach najbogatszych samorządów. Skrajny przykład stanowi najbogatsza w sensie podatkowym gmina w Polsce - Kleszczów. Jest to efekt lokalizacji na jej terenie dwu wielkich zakładów pracy: kopalni węgla brunatnego Bełchatów i związanej z nią elektrowni. Ta lokalizacja wynika z nieopłacalności transportu węgla brunatnego na dalszą odległość. W efekcie gmina Kleszczów przekracza wszelkie możliwe wskaźniki dochodowe na głowę mieszkańca.

Drugi przykład takiej negatywnie naznaczającej nazwy stanowi opłata uzdrowiskowa. Niekiedy jest określana jako „podatek od powietrza” i odłączona w świadomości od pakietu korzyści uzyskiwanych dzięki niej przez płacącego. Pojawia się w świadomości jako bezzasadny haracz nakładany na przybyszów, którzy i tak są źródłem lokalnych dochodów.

Z kolei Joseph Stiglitz wskazuje, że percepcja podatków zależy od społecznej recepcji grupy rządzącej. Pisze on w swojej Ekonomii sektora publicznego, że niekiedy podatek może być słusznie postrzegany jako rabunek. Staje się tak, „jeżeli proces polityczny w kraju zostaje oderwany od obywateli i jest wykorzystywany do transferu zasobów do grup sprawujących władzę, to rozróżnienie między opodatkowaniem a grabieżą staje się w najlepszym przypadku dyskusyjne"19. W podobny sposób może działać uzasadnione lub czysto stereotypowe postrzeganie władzy jako nieudolnej i marnotrawczej.

18 J. Osiński, Determinanty znaczenia instytucji współczesnego państwa. Neoliberalna ideologia a państwo, [w:] Współczesne państwo a dług publiczny, I. Zawiślińska (red.), Warszawa 2014, s. 199-224.

19 Cyt. za: M. Kosek-Wojnar, op. cit., s. 53. 


\section{Podatki - iluzje fiskalne a moralność}

Tu się dotyka ważnej kwestii - podatki a moralność. Podatek jest niekiedy postrzegany jako narzędzie sprawiedliwości społecznej. Tak postrzegają go aktualni i dawni teoretycy finansów. Jak pisał R. Wiśniewski, wprawdzie podatki to daniny, które mają charakter przymusowy, „ale w istocie wyrażają fiskalnie ujętą treść stosunku moralnego, łączącego jednostkę i wspólnotę"20. Podobnie kwestię tę interpretuje ekonomista katolicki Ignacy Czuma, stwierdzając, że podatek jest $\mathrm{w}$ istocie świadczeniem na rzecz zbiorowości. To świadczenie o wartości gospodarczej (pieniądz, dobro, usługa), jest obowiązkiem naturalnym, moralnym, który ujmuje się w szatę prawną ${ }^{21}$.

Także u samego Adama Smitha w jego zasadach podatkowych odnajdujemy wyraźnie aspekt moralny. Proponuje on zasadę równości obciążenia podatkowego. Ale równe w tym momencie oznacza - w równej proporcji do posiadanego majątku: „poddani każdego państwa powinni przyczyniać się do utrzymywania rządu w jak najściślejszym stosunku do ich możliwości, czyli proporcjonalnie do dochodu, jaki każdy z nich pod opieką państwa uzyskuje"22.

Moralny wymiar podatku może łatwo prowadzić do iluzji fiskalnych. Ich konsekwencją są postulaty wyższego obciążenia podatkami ludzi bogatych. Często słychać przekonania, że najwięcej płacić powinni najbogatsi i tym więcej, im są bogatsi. Takie postulaty zyskują łatwo poparcie. Związek takiego poglądu ze sprawiedliwością społeczną pozostaje $\mathrm{w}$ świadomości społecznej silny, a w niektórych krajach taki podatek jest nazywany solidarnościowym.

Ten typ podatku pojawia się $\mathrm{w}$ formie bezpośredniej i pośrednio - $\mathrm{w}$ formie podatku od luksusu. Ten drugi jest podwójnie uzasadniony, bo płacą go bogatsi od przedmiotów konsumpcji pokazowej, a jego świadczenie hamuje społecznie „zbyteczną" konsumpcję. W PRL występowały tzw. ceny drenażowe, stanowiące właściwie rodzaj podatku. Miały one na celu ściąganie pieniędzy z rynku i zmniejszania „nawisu” inflacyjnego. Dotyczyło to szeregu dóbr gospodarstwa domowego. Niekiedy można powiedzieć, że podatek przybiera charakter „zemsty". W tym samym okresie istniał tzw. podatek od nieewidencjonowanych źródeł dochodów („domiar”). Założenie o jego racji było silniejsze od zasady domniemania niewinności. Było to założenie, że bogactwo jest zawsze podejrzane samo przez się.

${ }^{20}$ Ibidem, s. 52.

${ }_{21}$ I. Czuma, Z etymologii i przekształceń znaczenia podatku, [w:] idem, O moralne podstawy ustroju. Wybór pism, Lublin 2007, s. 310.

22 A. Smith, Badania nad natura i przyczynami bogactwa narodów, t. 2, Warszawa 2007, s. 500-503. 
Niekiedy postrzega się w tym modelu podatków właściwą drogę do naprawy trudności budżetowych. Ze względu na znaczenie tej kwestii, warto przytoczyć pewne argumenty przeciwko nadmiernie progresywnemu podatkowi. Kontrargumenty sięgają po dwa aspekty - jest to wydajność źródła podatkowego i jego trwałość. W finansach publicznych przez pojęcie wydajności określa się, ile środków może uzyskać społeczeństwo z określonego źródła opodatkowania. Otóż takie podatki nie są wydajnym źródłem dochodów. Polska to kraj, w którym jest relatywnie mniej osób wysoko zarabiających, a tzw. współczynnik Giniego, wskazujący na skalę nierówności, jest niższy niż w innych krajach regionu ${ }^{23}$. Dodatkowo podatki wobec lepiej zarabiających są społecznie ryzykowne. To wynik zwrotnego oddziaływania podatku na swoje źródło przez osłabienie motywów do kontynuacji zachowania („karanie” za sukces) oraz drenaż środków na rozwój i reprodukcję gospodarki. Pokazuje to następujące porównanie: milion złotych uzyskanych od jednego podatnika i obciążenie miliona podatników po złotówce. To drugie jest mniej społecznie uciążliwe i szkodliwe.

\section{4. lluzje społeczne - geneza, trwanie i pokrewieństwo z mitami}

Iluzje fiskalne należą do innego porządku niż mity. Traktowane ich jako mitów ani nie ukazuje nieznanego oblicza iluzji fiskalnych, ani nie wzbogaca rozumienia mitów jako zjawiska politycznego. Ich istnienie wskazuje za to, że dziedzina, tak wydawałoby się zracjonalizowana i zmatematyzowana jak finanse publiczne, nie jest wolna od penetracji przez pozaekonomiczne wyobrażenia.

Są jednak podobieństwa. Mają i iluzje, podobnie jak mity, genezę społeczną. Są też nieprzypadkowe: mają określony kierunek i w świadomości społecznej pełnią ważne funkcje. Funkcja społeczna iluzji fiskalnych jest pokrewna do funkcji społecznej mitów - jak mity niosą w sobie i narzucają wzorzec normatywnego istnienia. Jest w nich zawarte "drugie dno" - wyobrażenia o pożądanym porządku społecznym. Jako całość są nośnikami wizji, a raczej iluzji pewnego sprawiedliwego porządku społecznego.

W tym przypadku można zaproponować trzy aspekty tego porządku społecznego, którego stworzenie obiecują iluzje fiskalne. Pierwszy z nich to koncepcja ustanawiania ładu moralnego przez podatki. Jest to realizacja idei sprawiedliwości wyrównującej, która określa i realizuje wzorzec „sprawiedliwego” rozkładu wkładów w życie zbiorowe. Drugim jest wizja państwa jako adresata roszczeń,

${ }^{23}$ Por. Miliarderów w Polsce na lekarstwo, http://samorzad.pap.pl/depesze/statystyka/ 157188/Z-miliarderami-bieda--Tylko-4-Polakow-ma-powyzej-1-000-000-000-dolarow- [dostęp: 10.05.2018]. 
wyposażonego w niewyczerpane zasoby, a nie w sumę prostą oddolnych składek, mających jako swą podstawową cechę skończoność. Po trzecie, jest to przekonanie, że zbiorowa sprawczość nie ma realnych granic. Może zorganizować bez przeszkód przestrzeń publiczną, tak aby stanowiła ona jej normatywne odbicie.

Iluzje fiskalne obok określonych wyobrażeń mają jeszcze jedną funkcję. Podtrzymują wyobrażenia społeczne w szczególny sposób, mianowicie poprzez uzasadnianie przekonań o możliwości ich łatwej realizacji. Jednocześnie wiążą się z poczuciem istnienia rozwiązań zagadnień trudnych i na dodatek związanych z koniecznością ofiar. Dają nadzieje, że społecznie pożądane cele można łatwo osiągać i to bez większych kosztów. Wystarczy tylko inna dystrybucja danin społecznych lub inne nakierowanie wydatków. Będą one nie tylko skuteczniejsze, ale na dodatek bardziej zgodne ze sprawiedliwością społeczną.

Wierze w siłę wyobrażeń sprzyja jeszcze inna ich właściwość. Jest to trochę moralność i hojność na rachunek cudzy, a także rozdawnictwo dóbr, których się nie posiada. Wykorzystuje się przy tym braki wyobraźni nieprzywykłej do operowania liczbami tej skali, a także brak świadomości, jak te wielkości powstają, jakie są tego konsekwencje, wreszcie jakie efekty przynosi takie lub inne ich wydatkowanie. Iluzja fiskalna „chroni” jej nosiciela przed wiedzą, że w ostatecznym efekcie zapłaci za nie albo sam wyborca $\mathrm{z}$ innymi ludźmi w podobnym do niego położeniu, albo przyszłe pokolenia. I że może też tak być, że będzie to znacznie więcej niż wynoszą dzisiejsze korzyści.

Zapotrzebowanie na taką wiarę rodzi się nieprzypadkowo. Za ich siłą i spontanicznym odradzeniem się stoi coś, co Monika Torczyńska nazwała „społecznym zapotrzebowaniem na iluzję"24. To właśnie społeczne zapotrzebowanie na iluzje powoduje trwałość i utrzymywanie się iluzji fiskalnych. Rzeczywistość polityczna dostarcza szeregu przesłanek do poszukiwania różnych iluzji, aby uratować wiarę nie tylko w demokrację, ale i lepszy świat. Iluzje fiskalne w tym pomagają. Dają swym wyznawcom swoistą „wiedzę" o świecie - wtajemniczają ich w nowy porządek, który w tych wyobrażeniach może istnieć mimo zdegradowanej normatywnie rzeczywistości. Dzieje się tak dzięki dostarczaniu podstaw wierze w realność takiego pożądanego porządku. To jest ważna różnica między iluzją a mitem - w micie ten właśnie aspekt podtrzymywania przekonań o możliwości zaistnienia ani nie jest tak widoczny, ani nie odgrywa tak ważnej roli ${ }^{25}$.

Ale iluzje fiskalne niosą duże niebezpieczeństwo dla swych nosicieli. Mogą stać się bazą populizmu fiskalnego. Populizm często uznaje się za zjawisko

\footnotetext{
${ }_{24}$ M. Torczyńska, O prawdzie, iluzjach i mitach w kontekście standardów demokratycznego państwa prawnego, [w:] Tworzenie iluzji społecznych. Wiedza w sferze publicznej, Studia nad wiedza, t. 5, J. Szymczyk, M. Zemło, A. Jabłoński (red.), Lublin 2012, s. 522.

25 Ibidem, s. 521.
} 
spowodowane przez cynicznych polityków, ale niekiedy jest to funkcja rywalizacji politycznej, zmuszającej polityków do mobilizacji stereotypów społecznych. Jego przyczyną są nie tylko same działania polityków, ale i świadomość społeczeństwa, która go umożliwia. Iluzje fiskalne dają populizmowi do rąk nie tylko argumenty, ale i potężną bazę społeczną. Jest ona tym niebezpieczniejsza, że wspiera się o wiele marzeń nieodłącznych od demokracji czy nawet idei godziwego życia. Iluzje fiskalne tworzą legitymację dla różnych działań społecznych: oczekiwań świadczeń, wydatków na rzecz innych czy systemu podatkowego. Iluzje ukierunkowują fiskalizm na określone grupy społeczne, odmawiając im legitymacji do posiadania majątku, ograniczają społecznie drażniącą ostentacyjną konsumpcję, realizują redystrybucję dochodu narodowego. Niekiedy nabierają charakteru aktu „słusznej” zemsty czy kary społecznej.

Specyfiką iluzji fiskalnych jest to, że nie tylko prowadzą do nierealnych dążeń. Mają jeszcze inne negatywne skutki społeczne. Konsekwencją iluzji jest utrata części dobrobytu społecznego (w rozumieniu Arthura Pigou ${ }^{26}$ ). Pod ich wpływem następuje strukturalne zniekształcenie wydatków społecznych w stosunku do ich optymalnego kształtu - odejście od najlepszej społecznej alokacji nakładów czy trwałego i ekonomicznie wydajnego systemu podatkowego. Negatywne efekty iluzji fiskalnych da się zilustrować przykładami. Może to być przesunięcie w stronę aktualnych, społecznie uzasadnionych wydatków, kosztem bardziej korzystnych wydatków rozwojowych. Nie zawsze także jednostkowa korzyść aktualna jest nią rzeczywiście. Nadmierny nacisk na wydatki socjalne może spowodować brak funduszy społecznych na inne ważne dziedziny, jak produkcja i reprodukcja kapitału ludzkiego (nauka, oświata i zdrowie). Jeśli istnieje przekonanie o wyższych niż realne przychodach społecznych, to

${ }^{26}$ Arthur Pigou był ekonomistą angielskim, który stworzył tzw. ekonomię dobrobytu (książka The Economics of the Welfare z 1920 roku). Rozwinął w niej koncepcję "dobrobytu” jako celu działań ekonomicznych: jednostkowych i zbiorowych. Jest to zmatematyzowana idea utylitarystyczna - maksymalnego szczęścia dla maksymalnej liczby ludzi, a w odniesieniu do podatków - zasada „najmniejszego całościowego poświęcenia”. Ale w tym ujęciu dobrobyt społeczny nie jest prostą sumą dobrobytów indywidualnych. Wprowadzenie koncepcji efektów zewnętrznych, korzyści lub strat innych ludzi z działań nie tylko jednostek, ale i aktorów ekonomicznych, społecznych i politycznych, rozszerza możliwości analityczne, jakie daje ta koncepcja. Przykładowo uznaje za niepożądane te działania, w których korzyści jednych aktorów są uzyskiwane kosztem innych. Pozwala także na ocenę zasadności interwencji państwa w ekonomię czy polityki redystrybucji. W przypadku polityk podatkowych rozważanych w tej części pracy, teoria ta wskazuje, że gdy zostaną one wprowadzone w życie, ich bilans społeczny może nie być dodatni, mimo tworzenia pewnych jednostkowych korzyści (omówienie teorii Pigou por. A. Michalewski, Ekonomia dobrobytu. Prezentacja i próba analizy, Warszawa 1972, s. 61-73 oraz J. Buchanan, op. cit., s. 172). 
ich efektem jest wykreowanie zbyt wielu programów. Da to w sumie mniejsze korzyści z powodu rozproszenia środków. Na przykład zbyt silny nacisk społeczny na rozszerzenie frontu rozbudowy infrastruktury może spowodować zamrożenie znaczącego kapitału zbiorowego w nadmiernie rozszerzonym froncie inwestycyjnym. Wywoła to w efekcie nie tylko obniżenie stopy zwrotu wydatków, ale nawet jej brak.

Skutki zbyt dużych podatków od wysokich dochodów są mało uświadamiane. Mogą generować zbyteczne obciążenie podatkowe, prowadzące do nieuświadamianej nieefektywności, związanej ze społecznymi konsekwencjami zbyt wysokiego opodatkowania najwyższych dochodów. Może to demotywować do ich osiągania lub spowodować ucieczkę kapitału do innych regionów, a nawet krajów. W efekcie następuje erozja podstawy podatkowej. Jest jeszcze jedna mniej uświadamiana konsekwencja iluzji fiskalnej tego rodzaju. Nacisk na „sprawiedliwy kształt” podatków może spowodować niewykorzystanie mniej „sprawiedliwych”, ale bardziej wydajnych sposobów samoopodatkowania (samofinansowania) społecznego.

Także niechętnie uznaje się za społeczną stratę skutki zbyt niskich podatków. Są one mniej uświadamiane niż konsekwencje ich nadmiernej wysokości. Znane są efekty nadmiernych podatków, ale mogą także występować efekty zbyt niskich podatków, kiedy przyrost dobrobytów prywatnych jest niższy od utraty korzyści z tytułu konsumpcji zbiorowej.

To najbardziej oczywiste przykłady, choć jest ich zapewne więcej. Przytaczane są, aby wskazać, że problem jest niebagatelny, o znaczących społecznie konsekwencjach. Iluzje mogą mieć jeszcze inne negatywne społeczne konsekwencji. Rozbudzają one daleko idące nadzieje i żądania. Dają asumpt do mobilizacji i wysiłku społecznego, lecz ich zdemaskowanie (które wcześniej lub później nadchodzi) nieuchronnie przynosi zawód i rezygnację. Skutkuje to erozją kapitału zaufania do państwa i prawa w skali zbiorowej. Następuje przez to obniżenie potencjału instytucjonalnego ważnych społecznych instytucji. W szczególności słabnie wiara w znaczenie głównej idei demokratycznego budżetu - wspólnego decydowania o przeznaczaniu zbiorowych zasobów na cele ogólne i realizacji przez to celu działania państwa - dobra wspólnego, w jego konkretnej postaci tu i teraz.

Sfera finansów państwa jest tą, gdzie społeczne dążenia i wartości stykają się z rzeczywistością w sposób najbardziej bolesny. Ale z kolei jest to miejsce, gdzie wartość uzbrojona w wiedzę o administracji publicznej, o społecznych skutkach nakładów państwa, może realnie wpływać na rzeczywistość. Iluzje fiskalne silnie dewastują tę możliwość, w miejsce wiedzy podsuwając złudzenia. 


\section{Zakończenie - iluzje społeczne a strukturalne cechy demokracji}

Iluzje społeczne dotyczą szerszego zjawiska polityki demokratycznej - podejmowania decyzji w warunkach niepełnej wiedzy i ułomnej kompetencji do ich adekwatnego przetworzenia przez kluczowych decydentów: obywateli czy wyborców. Analizowana sfera ma pewną zaletę analityczną. W przypadku iluzji fiskalnych ich koszty społeczne można wyliczyć i pokazać. Ich „iluzyjny charakter" jest także bardziej widoczny ze względu na to, że dotyczy rozwiniętej gałęzi wiedzy o społeczeństwie. W przypadku iluzji dotyczących innych dziedzin polityki jest to trudniejsze do policzenia, jak np. koszty suboptymalnego wyboru polityka.

Warto przywołać cybernetyczny model decydowania przez przeciętnego obywatela $\mathrm{w}$ demokracji, który przedstawił Ziemowit Pietraś na przykładzie decyzji wyborczej. Zgodnie z nim, przeciętny wyborca nie ma dostępu do pełnej informacji o sytuacji politycznej i na dodatek brakuje mu wiedzy na temat funkcjonowania systemu politycznego. Powstaje wtedy problem racjonalnego zachowania w sytuacji niepełnej informacji. Wyborcy rozwiązują go następująco - upraszczają nadmiernie skomplikowaną rzeczywistość, a decyzje podejmują w oparciu o kilka prostych reguł heurystycznych. Istotę tych reguł stanowi to, że podejmowane na ich podstawie decyzje mają wysoki odsetek trafności, ale $\mathrm{z}$ drugiej strony, nie zawierają one pełnej gwarancji osiągnięcia swego celu, a więc dokonania słusznego i uzasadnionego wyboru ${ }^{27}$. Mimo tego uproszczonego modelu powstawania decyzji politycznych i mimo zawartego w nich dość pesymistycznego spojrzenia na politykę, można jednak sądzić, że taki sposób decydowania o polityce przez obywateli jest prawidłowością trwałą.

Demokracja stwarza szeroką arenę dla wpływu iluzji na różne sfery tworzenia polityki, gdyż z definicji jest otwarta na postawy i opinie społeczeństwa. Jest więc strukturalnie na nie wrażliwa. Iluzje fiskalne, ich siła i niebezpieczne konsekwencje dla kraju, są argumentem na rzecz rozwoju wiedzy obywatelskiej i kompetencji demokratycznej. Stereotypy zmieniają się wolno. Jednak możemy przypuszczać, choć nie ma niestety pewności, że narastające doświadczenie i większa wiedza będą powodowały nacisk na ich zmianę w pozytywnym społecznie kierunku. Odrzucaniu populizmu fiskalnego służyć powinien wzrost zaufania w sferze rządzący-rządzeni. Zaufanie personalne zastępuje zaufanie oparte na zdolności oceny proponowanych działań, tam gdzie brak jest odpowiedniej wiedzy. Wprawdzie są to oczekiwania trudne do spełnienia, można jednak wyrazić nadzieję, że w przyszłości spełnią.

27 Z. Pietraś, Decydowanie polityczne, Warszawa-Kraków 1998, s. 453-455. 


\section{Bibliografia}

Backhaus J., Fiscal Sociology: What For?, https://www.uni-erfurt.de/fileadmin/ user-docs/Finanzwissenschaft/bibliothek/valedictory_lecture.pdf [dostęp: 1.05.2018].

Bowman K., Rugg A. (red.), Public Opinion on Taxes: 1937 to Today, www. aei.org/files/2012/04/09/-aei-public-opinion-study-on-taxes [dostęp: 1.11.2015].

Buchanan J., Finanse publiczne $w$ warunkach demokracji. Systemy fiskalne a decyzje indywidualne, Warszawa 1997.

Czuma I., Z etymologii i przekształceń znaczenia podatku, [w:] I. Czuma, O moralne podstawy ustroju. Wybór pism, Lublin 2007, s. 283-312.

Ferrari-Occionero M., Myśl socjologiczna Roberta Michelsa, „Studia Socjologiczne" 1985, nr 2, s. 161-172.

Gomułowicz A., Zasada sprawiedliwości podatkowej, Warszawa 2001.

Gomułowicz A., Zasady podatkowe wczoraj i dziś, Warszawa 2001.

Grądalski F., Wstęp do teorii opodatkowania, Warszawa 2004.

Guziejewska B., Iluzje fiskalne $w$ zdecentralizowanych systemach finansów publicznych, [w:] Finanse lokalne. Wybrane zagadnienia, L. Patrzałek (red.), Poznań 2009, s. 59-68.

Janicki M., Badania nad żądaniami, „Polityka” 2015, 18.03.

Komunikat BS/8/7/94 z dn. 17.01.1994 r., CBOS, Warszawa 1994.

Kosek-Wojnar M., Zasady podatkowe w teorii i praktyce, Warszawa 2012.

Mann F.K., Finanzsoziologie, [w:] Handwörterbuch der Sozialwissenchaften, t. 2, Stuttgart-Tübingen-Göttingen 1961, s. 642-647.

Michalewski A., Ekonomia dobrobytu. Prezentacja i próba analizy, Warszawa 1972.

Miliarderów w Polsce na lekarstwo, http://samorzad.pap.pl/depesze/statystyka/157188/Z-miliarderami-bieda--Tylko-4-Polakow-ma-powyzej-1-000000-000-dolarow- [dostęp: 10.05.2018].

Musgrave R., Musgrave P., Public Finance in Theory and Practice, New York 1989.

Osiński J., Determinanty znaczenia instytucji wspótczesnego państwa. Neoliberalna ideologia a państwo, [w:] Wspótczesne państwo a dług publiczny, I. Zawiślińska (red.), Warszawa 2014, s. 199-224.

Pareto V., Uczucia i działania: fragmenty socjologiczne, Warszawa 1994.

Pietraś Z., Decydowanie polityczne, Warszawa 1998.

Schmölders G., Finanz- und Steuerpsychologie, [w:] Handwörterbuch der Wirtschaftswissenschaft, t. 3, Stuttgart-New York-Tübingen-GöttingenZürich 1972-1983. 
Smith A., Badania nad natura i przyczynami bogactwa narodów, t. 2, Warszawa 2007.

Torczyńska M., O prawdzie, iluzjach i mitach $w$ kontekście standardów demokratycznego państwa prawnego, [w:] Tworzenie iluzji społecznych. Wiedza w sferze publicznej, Studia nad wiedza, t. 5, J. Szymczyk, M. Zemło, A. Jabłoński (red.), Lublin 2012, s. 515-528.

Zweig F., Przerzucanie podatków, Kraków 1923.

\begin{abstract}
Scholars working with public finance introduced a term fiscal illusions (James Buchanan). They are social stereotypes dealing with the matter of public finance: spendings and revenues. They result in strong pressure on public spendings. They are perceived separately from each other, especially spendings from revenues. They are very important socially and politically. They can be easily mobilized by political populists. Fiscal illusion are not myths because of lacking narrative elements. Though they are similar to them with their function of legitimize some social beliefs and their close relations to social values, and especially - to social justice. Fiscal illusions tend to direct fiscalism onto social groups of higher social status and to make taxation a mean of social redistribution not economic growth. The emergence and persistence of the fiscal illusion confirm the strength of political myths. They are able to penetrate even such a rational and calculable area as public finance.
\end{abstract}

Keywords: fiscal illusion, public finance 